\title{
Radyasyonun taşınması ve yayılımı hakkında öğrencilerin ve halkın görüşleri
}

\author{
Hüseyin AĞBULUT $\left.{ }^{*}\right]$ \\ Münir OKTAY ${ }^{[* *]}$
}

\begin{abstract}
Öz
Radyasyon gündelik hayatımızda iç içe olduğumuz bir gerçektir. Hayatın olağan akışı içerisinde yapay ve doğal kaynaklardan radyasyona maruz kalmaktayız. Maruz kaldığımız radyasyonun kaynağı yanı başımızdaki radyasyon yayan bir madde olabildiği gibi çok uzaktaki bir kaynak da olabilmektedir. Bu araştırmanın amacı, öğrencilerin ve halkın, radyasyonun taşınması ve yayılımı hakkındaki görüşlerini incelemektir. Araştırmanın çalışma grubunu, Derince Anadolu İmam Hatip Lisesi öğrencileri ve velilerinden oluşan, sistematik örnekleme yöntemi ile seçilen 90 kişilik öğrenci, 33 kişilik halk grubu oluşturmaktadır. Uygulama 2013-2014 eğitim öğretim döneminde yapılmıştır. Araştırmada veri toplama aracı olarak, araştırmacılar tarafından geliştirilen açık uçlu anket görüşmesi formu kullanılmıştır. Anket 30 maddeden oluşmaktadır. Araştırma sonunda elde edilen veriler frekans analizi, yüzde analiz ve betimsel analiz kullanılarak çözümlenmiştir. Araştırmada elde edilen bulgulara göre, öğrencilerin ve halkın radyasyon ve radyoaktiflik kavramlarını birbirine karıştırdıkları ve birbirlerinin yerine kullandıkları, yapay radyasyon kaynaklarını da radyoaktif madde olarak düşündükleri görülmektedir. Ayrıca araştırmada insanların, radyasyona maruz kalan maddelerin radyoaktif özellik kazanacaklarını ve bu maddelerin yapılarında zamanla radyasyon birikeceğini düşündükleri görülmüştür.
\end{abstract}

Anahtar kelimeler: Radyasyon, radyoaktiflik, radyoaktif madde, radyasyonun taşınması, radyasyonun yayılımı.

\section{Students' and public's view about the transportation and spread of radiation}

\begin{abstract}
Radiation is a reality of our daily lives. We are exposed to radiation from natural and man-made sources during regular flow of our lives. The source of the radiation we are exposed to can vary from a substance near us to a source far from us. The aim of this research is to investigate the views of students and public about the transportation and spread of radiation. The study group of the research included 90 students from Derince Anatolian Imam Hatip High School and and 33

[*] Dr., Başiskele Selim Yürekten Mesleki ve Teknik Anadolu Lisesi, huseyin.agbulut@atauni.edu.tr

${ }^{[* *}$ Prof. Dr. Karamanoğlu Mehmetbey Üniversitesi, Eğitim Fakültesi, Sınıf Eğitimi Bölümü,
\end{abstract} muniroktay@kmu.edu.tr 
parents and selected by systematic sampling method. The research was carried out in the 20132014 academic year. In this study, an open-ended questionnaire, developed by the researchers, was used as a data collection tool. The questionnaire consisted of 30 items. The data obtained at the end of the research were analyzed by using frequency, percent, and descriptive analysis. According to the findings obtained in the study, it was shown that the students and public confused the concepts of radiation and radioactivity; used those concepts interchangeably; and considered the man-made radiation sources as radioactive substances. In addition, it was found in this study that people thought the substances exposed to radiation gain radioactive features and they also thought that radiation would accumulate in the structure of that substances in time.

Keywords: Radiation, radioactivity, radioactive substance, transportation of radiation, spread of radiation.

\section{Giriş}

Radyasyonu değişik şekillerde tanımlamak mümkündür. Dural ve Ruacan (2001), radyasyonu "genel anlamda enerjinin uzayda dalgalar ya da tanecikler (fotonlar) halinde yayılmasıdır" olarak tanımlamışlardır. Radyasyon; değişik formları olan, dünya yaratıldığı andan itibaren var olan doğal bir enerjidir. Radyasyon görülemez, koklanamaz, tadılamaz ve hissedilemez ama çeşitli cihazlarla tespit edilebilir ve ölçülebilir (Fastman, 1998).

Radyasyon, iyonlaştırıcı ve iyonlaştırıcı olmayan şeklinde ikiye ayrılabilir. "İyonlaştırıcı radyasyon; iyonlaşabilen atomlardan veya iyonlaşabilen moleküllerden elektron koparmak için yeterli enerji taşıyan kuantumlara sahip olan herhangi bir elektromanyetik radyasyon türüdür. İyonlaştırıcı olmayan radyasyon ise iyonlaşabilen atomlardan veya moleküllerden elektron koparmak için yeterli enerji taşıyan kuantumlara sahip olmayan herhangi bir elektromanyetik radyasyon türüdür" (Cleveland ve Ulcek, 1999). Atomlardan ve moleküllerden elektron kopararak iyon oluşturabilecek enerjiye sahip yüksek enerjili X-1şınları ve gama ş̧ınları iyonlaştırıcı radyasyona örnek verilebilir. Yüksek enerjili iyonlaştırıcı elektromanyetik dalgalar, canlı hücrelerinde iyonlaşmaya neden olduğu için hücre yapısını bozabilmekte, DNA yapısında hasara yol açabilen moleküler değişikliklere neden olabilmektedirler. İyonize radyasyon, bir şeyin kimyasal yapısını ve canlı dokusunun yapısını değiştirebilir (Fastman, 1988). Görünür 1şık, kızılötesi radyasyon ve RF (radyo frekans) dalgalar gibi daha düşük enerjili elektromanyetik dalgalar ise iyonlaştırıcı olmayan radyasyona örnek olarak verilebilir.

Radyasyon, radyoaktif madde, radyasyona maruz kalma, radyasyonun taşınması ve yayılımı gibi konular birbirine karıştırılan konulardır. Yapılan birçok bilimsel çalışmada bu kavramların birbirleri yerine kullanıldığ 1 görülmektedir (Eijkelhof, 1996; Henriksen, 1996; Lijnse, Eijkelhof, Klaassen ve Scholte, 1990; Millar ve Gill, 1996). Orta ve orta üstü fen sinıflarında ve değişik radyoaktivite deneyimine sahip 14-18 yaş öğrencilerle yapılan röportaj ve yazılı anket sonuçlarında, radyoaktivite ve radyasyon konularındaki farklılığın anlaşılamadığ yaygın olarak görülmektedir (Eijkelhof; aktaran, Millar ve diğerleri, 1990). Röportaj ve anket çalışmaları, çocukların radyasyon olayını nasıl anladıklarını açı̆̆a çıkarmaktadır. Örneğin, çoğu öğrenci bilimsel görüşten farklı olarak "radyasyon emilir" şeklinde bir görüşe sahiptir. Birçok kişi, 
radyasyon kullanılarak sterilize edilen şırınga ve kıyafetlerin radyoaktif olacağını ve daha sonra bu maddelerin kendilerinin radyasyon yayacağını düşünmektedir. Aynı şekilde birçok öğrenci, röntgen odalarının duvarlarının ve havasının da radyoaktif olacağını, iyi havalandırılarak bu odalarda radyasyonun birikmesinin engelleneceğini düşünmektedir. Bu röportaj ve anket sonuçları, öğrencilerin radyasyon ve radyoaktivite kavramlarını ayrıştıramadıklarını göstermektedir (Millar, Klaassen ve Eijkelhof, 1990).

Öğrenciler, bir maddenin radyasyona maruz kalması durumunda radyasyonun maddeye hapsolacağını ve bir daha çıkmayacağını, radyasyonun o maddede birikeceğini, biriken radyasyon miktarı belli bir seviyeye ulaşınca artık o maddenin kendisinin de radyasyon yaymaya başlayacağını (Eijkelhof, 1996; Henriksen, 1996), suyun süngerde emilmesi gibi radyasyonun da maddeler tarafından emildiğini ve kapalı alanlarda hapsedildiğini düşünmektedirler (Eijkelhof, 1990; Prather ve Harrington, 2001).

Radyasyon ve radyoaktivitekonularında yapılan çalışmalarda insanların, tıbbiamaçlıkullanılan $\mathrm{x}$-ışını (x-ray) odalarındaki duvarların radyasyonla dolduğuna, bu duvarların radyoaktif atık olarak değerlendirilmesi gerektiğine ve bu odadaki nesnelerin radyasyon yaydığına inandıkları görülmüştür (Eijkelhof, 1996; Janssen ve Wellens, 1989; Mubeen, Abbas ve Nisar, 2008). Ayrıca, deneysel amaçlarla radyasyona tabi tutulmuş deney hayvanlarına bakan işçilerin kendilerinin de radyasyona maruz kalacakları ve kaza sonucu radyasyon almış bir endüstri işçisinin, arkadaşları ve komşuları tarafından radyoaktif madde olarak düşünüldüğü görülmüştür (Eijkelhof, 1996).

Radyasyonun canlı sağlığına etkileri konusunda da değişik düşünceler vardır. Maruz kalınan radyasyonun canlının genetik yapısını değiştirmesi ve sonraki nesilleri de etkilemesi; maruz kalınan radyasyonun cinsi, dozu, etkilenme süresi, etkilenen bölge, radyasyon kaynağı ile canlı arasındaki mesafe gibi birçok faktöre bağlı olmasına rağmen, radyasyonun insan sağlığına zarar vereceği, hücrenin yapısını bozacağı ve kalıtsal hastalıklara yol açacağı şeklinde halk arasında yaygın bir kanı vardır (Matsuura ve Iırı, 1994). Öğrencilerin, radyasyonun insan sağlı̆̆ına zarar vereceğini, kansere, üreme bozukluklarına, saç ve deri döküntülerine ve yanıklara sebep olacağını ifade ettikleri ama hangi dozlarda bu etkilerin görüleceği konusunda bir şey söylemedikleri görülmektedir (Eijkelhof ve Millar; aktaran, Henriksen, 1996).

$\mathrm{Bu}$ çalışmada, ortaöğretim öğrencilerinin ve halkın, radyasyonun taşınması ve yayılımı hakkındaki düşüncelerini ortaya çıkarmak amaçlanmıştır. Bu konuda Türkiye’de yeterince araştırma yapılmadığı göz önünde bulundurulduğunda, araştırma sonuçlarına bakarak Türkiye'deki sonuçlarla dünyanın değişik yerlerinde yapılan diğer araştırma sonuçlarını karşılaştırma imkânı olabilecektir.

\section{Yöntem}

Eğitim bilimlerinde yapılan çalışmalarda kullanılan araştırma yöntemlerinde, nicel ve nitel araştırma yöntemleri gibi farklı yöntemlerin kesiştikleri ve sıklıkla bir arada kullanıldıkları görülmektedir (Baran, 2013; McMillan ve Schumacher, 2006). Araştırmanın nitel bir araştırma 
olmasıyla birlikte, araştırmaya yönelik elde edilen veriler yüzde ve frekans değerleriyle nicelleştirilmiştir.

\section{Çalışma grubu}

Araştırmanın çalışma grubunu 90 kişilik öğrenci ve 33 kişilik halk grubu oluşturmaktadır. Öğrenci grubu, Derince Anadolu İmam Hatip Lisesi öğrencilerinden, halk grubu ise aynı okulun öğrenci velilerinden, seçkisiz örnekleme türlerinden sistematikörnekleme yöntemi ile seçilmesiyle oluşturulmuştur. Sistematik örneklemede, örnekleme dâhil edilecek bireyler, evrenden her birim veya bireyin belirli ölçütlere göre, belirli aralıklarla seçilmesiyle oluşturulur (Yıldırım ve Şimşek, 2008). Çalışma grubu, 9.sınıf, 10.sınıf ve 11.sınıf şubelerindeki öğrencilerden oluşmaktadır. Şubelerdeki öğrencilerin seçimi ise, yine sistematik örnekleme yöntemine göre yapılmıştır. Öğrenci numaralarına göre oluşturulan sınıf listeleri alınmış ve listenin başından itibaren sıraya göre tek sayılı sıradaki öğrencilerin seçilerek örnekleme dâhil edilmesiyle çalışma grubu oluşturulmuştur. Böylece örneklem grubunun evreni temsil etmesi sağlanmıştır. Çalışmanın halk grubu ise okuma yazma bilen öğrenci velilerinden oluşmuştur. Halk grubundaki velilerin, çalışmaya katılan öğrencilerin velilerinden olmaması sağlanmıştır. Araştırma, 2013-2014 eğitimöğretim yılı içerisinde beş haftalık bir zaman sürecinde yapılmıştır.

\section{Veri toplama araçları}

Araştırmada veri toplama aracı olarak açık uçlu anket görüşmesi kullanılmıştır. Açık uçlu anket görüşmesinde öğrenci ve halk grubunu radyasyonun taşınması ve yayılması konusundaki görüşlerini görmek amaçlanmıştır. Ankette yer alan maddelerin ihtiyaç duyulan verileri toplamada ne kadar kullanışlı olduğunu belirlemek için uzman görüşü alınmıştır. Anketin kapsam geçerliliğini sağlamak amacıyla konu hakkında yapılan literatür çalışmaları, ders kitapları ve konuyla ilgili medya yayınları incelenmiş ve anket soruları hazırlanmıştır. Hazırlanan açık uçlu anket sorularının asıl çalışmaya uygun olup olmadığını görmek amacıyla; 60 kişilik öğrenci ve 50 kişilik halk grubu olmak üzere toplam 110 kişiyle anketin ön uygulaması yapılarak yüksek oranda cevapsız bırakılan sorular anketten çıkarılmış ve uzman görüşü de alınarak asıl çalışma için anket hazır hale getirilmiştir (Kilinç ve Salman, 2007; Oppenheim, 1966).

\section{Verilerin analizi}

Verilerin analizinde, çalışmada kullanılan açık uçlu ankete verilen cevaplar incelenerek kodlanmış ve belli kategorilere ayrılmıştır. Oluşturulan kodlara göre anketin her bir maddesine verilen cevapların frekans ve yüzdelik değerleri tablolar haline getirilerek nitel veriler, frekans ve yüzdelik oran gibi nicel verilere dönüştürülmüştür. Oluşturulan kodların hangi sıklıkta tekrar edildiğini görmek için verilerin yüzde hesaplamalarla verilmesi nitel araştırmalarda en sık kullanılan veri analiz yöntemidir (Tutty, Rothery ve Grinnell; aktaran, Yıldırım ve Şimşek, 2008). Verilerin analizinde betimsel ve içerik analizi kullanılmıştır. Ayrıca nitel veriler, frekans ve yüzde değerleri şeklinde nicelleştirilmiştir. Betimsel analizde görüşülen veya gözlenen bireylerin görüşlerini çarpıcı biçimde yansıtmak amacıyla doğrudan alıntılara sık sık yer verilir (Yıldırım ve Şimşek, 2008, s.224). 
Çalışmada, araştırmanın geçerliği sağlamak amacıyla veri toplama araçlarının oluşturulması ve verilerin analizi aşamasında uzman görüşü alınmıştır. Ayrıca araştırmacının; araştırmaya katılan öğrencilerin ders öğretmeni olması, çalışmanın halk grubunu oluşturan velilerle görüşeme imkânının olması, öğrencilerle hafta içi okul saatlerinde birlikte olması, araştırma ortamına yakınlığı, çalışmanın geçerliğini artıran faktörlerdir. Araştırmanın güvenirliğini sağlamak için veri toplama araçları açık şekilde tanımlanmış, çalışmanın örneklem grubunun kimlerden oluştuğu ve hangi yöntemlerle nasıl seçildiği ve çalışma zamanı belirtilmiştir. Bununla birlikte, güvenirliği artırmak için araştırmacının konumu açık şekilde belirtilmiştir. Araştırmacının, çalışma grubundaki öğrencilerin ders öğretmeni olduğu ve velilerle doğrudan görüşebildiği belirtilmiştir (Yıldırım ve Şimşek, 2008, s.266).

\section{Bulgular}

$\mathrm{Bu}$ bölümde araştırmacılar tarafından hazırlanan açık uçlu anket görüşmesine öğrencilerin ve halkın verdikleri cevaplar ve bu cevaplara ilişkin kodların yüzde-frekans değerleri tablolar halinde verilmiştir. Kodlar oluşturulurken, cevapsız bırakılan sorular "sıfır veri" şeklinde, soru ile ilgili olmayan anlamsız cevaplar ise "anlamsız veri” şeklinde kodlanmıştır. Ayrıca öğrencilerin ve halkın sorulara verdikleri cevaplardan bazıları doğrudan alıntılarla gösterilmiştir.

Tablo I.

"Radyasyon Bir Bölgeden Başka Bir Bölgeye Yaylır mı? Yayılacağını Düşünüyorsanız, Sizce Nasıl Yayılıyor Olabilir?" Sorusuna Verilen Cevapların Kodlara Göre Dağılımı.

\begin{tabular}{|l|c|c|c|c|}
\hline & \multicolumn{2}{|c|}{ Öğrenci (n=90) } & \multicolumn{2}{|c|}{ Halk $(\mathbf{n}=\mathbf{3 3})$} \\
\hline Kod & $f$ & $\mathbf{9}$ & $f$ & $\mathbf{9}$ \\
\hline Sıfır veri & 2 & $\mathbf{2 , 2}$ & 3 & $\mathbf{9 , 1}$ \\
\hline Bilmiyorum & 18 & $\mathbf{2 0 , 0}$ & 2 & $\mathbf{6 , 1}$ \\
\hline Anlamsız veri & 2 & $\mathbf{2 , 2}$ & 2 & $\mathbf{6 , 1}$ \\
\hline Yayılmaz & 6 & $\mathbf{6 , 7}$ & 3 & $\mathbf{9 , 1}$ \\
\hline İletişim araçları ile yayılır & 13 & $\mathbf{1 4 , 4}$ & 3 & $\mathbf{9 , 1}$ \\
\hline Nasıl olduğunu bilmiyorum ama yayılır & 24 & $\mathbf{2 6 , 8}$ & 8 & $\mathbf{2 4 , 2}$ \\
\hline Dalgalar halinde yayılır & 20 & $\mathbf{2 2 , 2}$ & 5 & $\mathbf{1 5 , 2}$ \\
\hline Hava, rüzgâr, yağmur, toprak ile yayılır & 2 & $\mathbf{2 , 2}$ & 7 & $\mathbf{2 1 , 1}$ \\
\hline Radyasyona maruz kalmış canlılarla yayılır & 2 & $\mathbf{2 , 2}$ & 0 & $\mathbf{0 , 0}$ \\
\hline Işınlarla yayılır & 1 & $\mathbf{1 , 1}$ & 0 & $\mathbf{0 , 0}$ \\
\hline
\end{tabular}

Konuyla ilgisi olmaya cevapların \% dağılımı;

$$
\text { Öğrenci grubunda Halk grubunda }
$$

$\begin{array}{lcc}\text { Sifır veri } & 2,2 & 9,1 \\ \text { Bilmiyorum } & 20,0 & 6,1 \\ \text { Anlamsız veri } & 2,2 & 6,1 \\ \text { Toplam } & 24,4 & 21,3 \text { şeklindedir. }\end{array}$


Yani konuyla ilgili olmayan cevaplar (sıfır veri ve anlamsız veri) ve "bilmiyorum" şeklinde verilen cevapların toplamının, öğrenci grubunda \%24,4 halk grubunda ise \%21,3 olduğu görülmektedir. Öğrenci grubunun \%2,2'sinin, halk grubunun ise \%21,1'inin radyasyonun hava, rüzgâr, yağmur ve toprak yoluyla yayıldı̆̆ını söyledikleri görülmektedir.

Öğrencilerin ve halkın, "Radyasyon bir bölgeden başka bir bölgeye yayılır mı? Yayılacağını düşünüyorsanız, sizce nasıl yayılıyor olabilir?” sorusuna verdikleri cevaplardan bazıları aşağıda verilmiştir.

Nasıl yayıldığını bilmiyorum ama yayılır (Ö6)

Dalgalar halinde yayılır (Ö7)

Mikroorganizmalarla dağılır (Ö20)

Herkeste telefon olduğu için yayılır (Ö22)

Cep telefonları ile yayılır (Ö12)

Direklerdeki teller üzerinden yayılır (Ö31)

Radyasyon havada uçan bir varlık, evet yayılır ( $\mathrm{H} 4)$

İki kişi telefonda görüşürken birinden diğerine yayılır (H26)

Tablo 2.

"Radyasyonlu Bir Bölgede Yetişen Otlarla Beslenen Bir Koyunun Etini Yiyen Veya Radyasyona Maruz Kalmış Bir Ineğin Sütünü Içen Birine Radyasyonun Geçebileceğine Inanıyor musunuz?" Sorusuna Verilen Cevapların Kodlara Göre Dă̆ııımı.

\begin{tabular}{|l|c|c|c|c|}
\hline & \multicolumn{2}{|c|}{ Öğrenci (n=90) } & \multicolumn{2}{|c|}{ Halk (n=33) } \\
\hline Kod & $f$ & $\%$ & $f$ & $\%$ \\
\hline Sifir veri & 0 & $\mathbf{0 , 0}$ & 2 & $\mathbf{6 , 1}$ \\
\hline Bilmiyorum & 7 & $\mathbf{7 , 8}$ & 2 & $\mathbf{6 , 1}$ \\
\hline Anlamsiz veri & 3 & $\mathbf{3 , 3}$ & 1 & $\mathbf{3 , 0}$ \\
\hline Evet & 52 & $\mathbf{5 7 , 8}$ & 23 & $\mathbf{6 9 , 6}$ \\
\hline Hayır & 28 & $31, \mathbf{1}$ & 5 & $\mathbf{1 5 , 2}$ \\
\hline
\end{tabular}

Konuyla ilgisi olmayan cevaplar ve "bilmiyorum" şeklinde verilen cevapların toplamının öğrenci grubunda \%11,1 olduğu, halk grubunda ise \%15,2 olduğu görülmektedir. Öğrenci grubunun \%57,8'inin, halk grubunun ise \%69,6’sının radyasyonlu bir bölgede yetişen otlarla beslenen bir koyunun etini yiyen veya radyasyona maruz kalmış bir ineğin sütünü içen birine radyasyonun geçebileceğini söyledikleri görülmektedir.

Öğrencilerin ve halkın, "Sizce, radyasyonlu bir bölgede yetişen otlarla beslenen bir koyunun etini yiyen veya radyasyona maruz kalmış bir ineğin sütünü içen birine radyasyonun geçebileceğine inanıyor musunuz?” sorusuna verdikleri cevaplardan bazıları aşağıda verilmiştir.

İnsanlar etini ve sütünü kullandıkları için evet (Ö19)

Et ateş üstünde pişirildiği zaman radyasyon kalmaz (Ö79)

Radyasyon olmaz ama besin değerinin olacağını sanmıorum $(\mathrm{H} 24)$

Kesinlikle bir etkisi vardır inanıyorum (H11) 
Marmara Üniversitesi Atatürk Eğitim Fakültesi Eğitim Bilimleri Dergisi / Journal of Educational Sciences YIl: Haziran 2016 • Cilt-Sayı $44 \cdot$ ISSN: I300-8889 • ss. I-I3

\section{Tablo 3.}

"Radyoaktif Atıkların Boşaltıldığı Bir Nehirde Yaşayan Balıkları Yiyen Insanların Vücutlarında Sizce Radyoaktif Madde Görülür mü??' Sorusuna Verilen Cevapların Kodlara Göre Dağılımı.

\begin{tabular}{|l|c|c|c|c|}
\hline & \multicolumn{2}{|c|}{ Öğrenci $(\mathbf{n}=\mathbf{9 0})$} & \multicolumn{2}{|c|}{ Halk (n=33) } \\
\hline Kod & $f$ & $\%$ & $f$ & $\%$ \\
\hline Sifir veri & 1 & $\mathbf{1 , 1}$ & 2 & $\mathbf{6 , 1}$ \\
\hline Bilmiyorum & 14 & $\mathbf{1 5 , 6}$ & 3 & $\mathbf{9 , 1}$ \\
\hline Anlamsiz veri & 4 & $\mathbf{4 , 4}$ & 1 & $\mathbf{3 , 0}$ \\
\hline Evet & 56 & $\mathbf{6 2 , 2}$ & 26 & $\mathbf{7 8 , 8}$ \\
\hline Hayır & 15 & $\mathbf{1 6 , 7}$ & 1 & $\mathbf{3 , 0}$ \\
\hline
\end{tabular}

Konuyla ilgisi olmayan cevaplar ve "bilmiyorum" şeklinde verilen cevapların toplamının öğrenci grubunda \%21,1 olduğu, halk grubunda ise \%18,2 olduğu görülmektedir. Öğrenci grubunun \%16,7’sinin, halk grubunun ise \%3,0’ünün, radyoaktif atıkların boşaltıldığg sularda yaşayan balıklarda radyoaktif madde görülmeyeceğini söyledikleri görülmektedir.

Öğrencilerin ve halkın, "Radyoaktif atıkların boşaltıldığ insanların vücutlarında sizce radyoaktif madde görülür mü?” sorusuna verdikleri cevaplardan bazıları aşağıda verilmiştir.

Bazı tıp hocaları olabilir diyor ama bence hayır (Ö17)

Emin değilim (Ö42)

Sonuçta balığın kendisi yeniliyor, evet (Ö72)

Olabilir de olmayabilir de (Ö89)

Evet, insan vücudunda birikerek hastalığa sebep olur (H20)

Kismen (H26)

\section{Tablo 4.}

"Radyasyona Maruz Kalmış Kişiler; Kullandıkları Eşyalar, Kan veya Ter Yolu ile Başkalarına da Radyasyonu Bulaştırabilirler mi?" Sorusuna Verilen Cevapların Kodlara Göre Dağılımı.

\begin{tabular}{|l|c|c|c|c|}
\hline & \multicolumn{2}{|c|}{ Öğrenci $(\mathbf{n = 9 0}$} & \multicolumn{2}{|c|}{ Halk (n=33) } \\
\hline Kod & $f$ & $\%$ & $f$ & $\%$ \\
\hline Sifir veri & 2 & $\mathbf{2 , 2}$ & 1 & $\mathbf{3 , 0}$ \\
\hline Bilmiyorum & 17 & $\mathbf{1 8 , 9}$ & 6 & $\mathbf{1 8 , 2}$ \\
\hline Anlamsiz veri & 3 & $\mathbf{3 , 3}$ & 0 & $\mathbf{0 , 0}$ \\
\hline Evet & 40 & $\mathbf{4 4 , 4}$ & 19 & $\mathbf{5 7 , 6}$ \\
\hline Hayır & 28 & $\mathbf{3 1 , 2}$ & 7 & $\mathbf{2 1 , 2}$ \\
\hline
\end{tabular}

Konuyla ilgisi olmayan cevaplar ve "bilmiyorum" şeklinde verilen cevapların toplamının öğrencilerde \%24,4 olduğu, halk grubunda ise \%21,2 olduğu görülmektedir. Öğrenci grubunun 
\%44,4'ünün, halk grubunun ise \%57,6'sının radyasyona maruz kalmış kişilerin kullandıkları eşyalar, kan veya ter yolu ile başkalarına da radyasyonu bulaştırabileceklerini söyledikleri görülmektedir.

Öğrencilerin ve halkın, "Radyasyona maruz kalmış kişiler; kullandıkları eşyalar, kan veya ter yolu ile başkalarına da radyasyonu bulaştırabilirler mi?” sorusuna verdikleri cevaplardan bazıları aşağıda verilmiştir.

Kan yoluyla olabilir (Ö27)

Kan yoluyla olur ama ter yoluyla olmaz (Ö57)

Başkalarına bulaşmaz (H20)

Tablo 5.

"Alışveriş Merkezlerinin, Havaalanlarının, Devlet Dairelerinin vb. Yerlerin Girişlerine Konulan, Güvenlik Amacıyla lçinden Geçtiğimiz Kutu Şeklindeki Metal Detektörlerinin Yaydığı Radyasyon Sizce Insan Vücudunda Birikir mi?"' Sorusuna Verilen Cevapların Kodlara Göre Dă̆ılımı.

\begin{tabular}{|l|c|c|c|c|}
\hline & \multicolumn{2}{|c|}{ Öğrenci (n=90) } & \multicolumn{2}{c|}{ Halk (n=33) } \\
\hline Kod & $f$ & $\%$ & $f$ & $\%$ \\
\hline Sifir veri & 3 & $\mathbf{3 , 3}$ & 1 & $\mathbf{3 , 0}$ \\
\hline Bilmiyorum & 28 & $\mathbf{3 1 , 1}$ & 7 & $\mathbf{2 1 , 2}$ \\
\hline Anlamsiz veri & 2 & $\mathbf{2 , 2}$ & 3 & $\mathbf{9 , 1}$ \\
\hline Evet & 37 & $\mathbf{4 1 , 1}$ & 16 & $\mathbf{4 8 , 5}$ \\
\hline Hayır & 20 & $\mathbf{2 2 , 3}$ & 6 & $\mathbf{1 8 , 2}$ \\
\hline
\end{tabular}

Konuyla ilgisi olmayan cevaplar ve "bilmiyorum" şeklinde verilen cevapların toplamının öğrenci grubunda \%36,6 olduğu, halk grubunda ise \%33,3 olduğu görülmektedir. Öğrenci grubunun \%41,1'inin, halk grubunun ise \%48,5'inin metal detektörlerinden yayılan radyasyonun insan vücudunda biriktiğini düşündükleri görülmektedir.

Öğrencilerin ve halkın, "Alışveriş merkezlerinin, havaalanlarının, devlet dairelerinin vb. yerlerin girişlerine konulan, güvenlik amacıyla içinden geçtiğimiz kabin şeklindeki metal detektörlerinin yaydığı radyasyon sizce insan vücudunda birikir mi?” sorusuna verdikleri cevaplardan bazıları aşağıda verilmiştir.

Sadece metal şeylerde görülür, insana bir şey yapmaz (Ö19)

Bu cihazlar zararlıymış ama birikir mi bilmiyorum (Ö73)

Çok az birikir ama o kadarı etkili olmaz (Ö81)

Radyoaktif madde yaydığı için birikir (H11)

Radyasyon birikiminin neticesinde zamanla insanlarda hastalık oluşur (H20) 
Marmara Üniversitesi Atatürk Eğitim Fakültesi Eğitim Bilimleri Dergisi / Journal of Educational Sciences YIl: Haziran 2016 • Cilt-Sayı $44 \cdot$ ISSN: I300-8889 • ss. I-I3

\section{Tablo 6.}

"Sizi Etkileyen Bir Radyasyonun, Doğacak Çocuklarınızı da Etkileme Olasılığı Var mıdır?" Sorusuna Verilen Cevapların Kodlara Göre Dă̆ııımı.

\begin{tabular}{|l|c|c|c|c|}
\hline & \multicolumn{2}{|c|}{ Öğrenci (n=90) } & \multicolumn{2}{|c|}{ Halk (n=33) } \\
\hline Kod & $f$ & $\%$ & $f$ & $\%$ \\
\hline Sifır veri & 1 & $\mathbf{1 , 1}$ & 5 & $\mathbf{1 5 , 2}$ \\
\hline Bilmiyorum & 14 & $\mathbf{1 5 , 6}$ & 1 & $\mathbf{3 , 0}$ \\
\hline Anlamsız veri & 1 & $\mathbf{1 , 1}$ & 1 & $\mathbf{3 , 0}$ \\
\hline Evet, mutasyonla, genlerle & 62 & $\mathbf{6 8 , 9}$ & 24 & $\mathbf{7 2 , 8}$ \\
\hline Hayır & 12 & $\mathbf{1 3 , 3}$ & 1 & $\mathbf{3 , 0}$ \\
\hline Radyasyonun türüne, dozuna, alınan bölgeye göre değişir & 0 & $\mathbf{0 , 0}$ & 1 & $\mathbf{3 , 0}$ \\
\hline
\end{tabular}

Konuyla ilgisi olmayan cevaplar ve "bilmiyorum" şeklinde verilen cevapların toplamının öğrenci grubunda $\% 17,8$ olduğu, halk grubunda ise $\% 21,2$ olduğu görülmektedir. Öğrenci grubunun \%68,9'unun, halk grubunun ise \%72,8'inin mutasyona sebep olan radyasyondan dolayı, bizi etkileyen radyasyonun doğacak çocuğumuzu da etkileyeceğini düşündükleri görülmektedir.

Öğrencilerin ve halkın, "Sizi etkileyen bir radyasyonun, doğacak çocuklarınızı da etkileme olasılığı var mıdır?” sorusuna verdikleri cevaplardan bazıları aşağıda verilmiştir.

Kesinlikle evet (Ö35)

Çocuk anne karnında besleniyor sonuçta evet (Ö72)

Yüzde yüz var (H6)

Çocuklarımız sakat doğar (H31)

Çernobil patlaması olduğunda anne karnındaki bebekler sakat doğdular (H32)

\section{Tartışma ve sonuç}

$\mathrm{Bu}$ bölümde, öğrenci ve halka uygulanan açık uçlu anket görüşmesi sonrası elde edilen bulgulara göre varılan sonuçlara yer verilmiştir.

Radyoaktif maddeler birer radyasyon kaynağı oldukları için bu maddelerin iletimi veya taşınması ile radyasyon da iletilmiş ve taşınmış olur. Radyoaktif maddeler yağmurun etkisiyle, toprak hareketliliğiyle veya rüzgârın etkisiyle küçük radyoaktif parçacıkların yer değiștirmesi sonucu çok uzak bölgelere kadar taşınabilmekte ve iletilebilmektedir. Radyasyona maruz kalmış bir canlı, hücrelerinde radyoaktif madde bulundurmuyorsa bu canlının radyasyon yayması veya gittiği başka bölgelere radyasyonu taşıması veya iletmesi mümkün değilken, çalışmadaki "Radyasyon bir bölgeden başka bir bölgeye yayılır mı? Yayılacağını düşünüyorsanız, sizce nasıl yayılıyor olabilir?" sorusuna verilen cevaplar incelendiğinde, öğrenci ve halk grubunun, radyasyona maruz kalmış kişilerin de radyasyon yaydığı düşüncesinde oldukları anlaşılmaktadır. Aynı soruya, "nasıl olduğunu bilmiyorum ama yayılır” şeklinde verilen cevapların fazlalığından (öğrenci grubunda $\% 26,8$, halk grubunda \%24,2) radyasyonun iletiminin ve taşınmasının nasıl 
olduğu konusunda her iki grubun da herhangi bir bilgisinin olmadığı anlaşılmaktadır. Ayrıca aynı soruya "cep telefonlarıyla yayılır" şeklinde verilen cevaplardan, insanların cep telefonlarını radyoaktif bir madde olarak gördükleri ve cep telefonlarının bir yerden başka bir yere taşınmasıyla radyasyonun da taşındığını ve iletildiğini düşündükleri anlaşılmaktadır. Kullanım esnasında radyasyon yaydığı bilindiğinden dolayı insanlar cep telefonunu radyoaktif bir madde olarak görüyor olabilirler. Literatürde yapılan çalışmalar incelendiğinde, insanların radyasyona maruz kalmış maddeleri radyoaktif madde olarak düşündüklerini gösteren çalışmalar olmasına rağmen (Eijkelhof ve Millar, 1988; Henriksen, 1996; Henriksen ve Jorde, 2001; Lijnse, Eijkelhof, Klaassen ve Scholte, 1990; Millar ve Gill, 1996; Nakipoğlu ve Bülbül, 2000; Neumann ve Hopf, 2012; Yalçın ve Kılıç, 2005), cep telefonu gibi, kapalı olduğunda radyasyon yaymayan ama sadece kullanım esnasında radyasyon yayan maddeleri de radyoaktif birer madde olarak düşündüklerini gösteren herhangi bir çalışmaya rastlanmamaktadır. Bu yönüyle yapılan çalışma bu konuda literatüre bir katkıda bulunabilir.

Radyasyonlu bölgelerde yetişen otlarda radyoaktif madde örnekleri varsa, yani bu otlarda radyoaktif madde birikmişse, bu otları yiyen hayvanların etinde ve sütünde de radyoaktif maddeye rastlanır. Ancak, radyasyona maruz kalmış otları yiyen veya doğrudan radyasyona maruz kalan hayvanların kendileri radyoaktif özellik kazanmayacakları için bu hayvanların eti veya sütü radyasyon yaymayacaktır. Çalışmada öğrenci ve halk grubunun, radyasyonlu bölgelerde yetişen otlarda radyoaktif madde birikmese bile, bu bölgelerdeki otların radyoaktif özellik kazandığını ve radyasyona maruz kalmış otları yiyen canlılarında da radyasyona maruz kalacaklarını düşündükleri görülmektedir. Radyasyona maruz kalan maddelerin de radyoaktif özellik kazanacağı şeklindeki bu düşünce, literatürde konuyla ilgili yapılan çalışma sonuçlarıyla örtüşmektedir (Eijkelhof, 1996; Henriksen ve Jorde, 2001; Lijnse ve diğerleri, 1990; Millar ve Gill, 1996; Millar ve diğerleri, 1990; Prather, 2005).

Çalışmaya katılan kişilerin önemli bir kısmının (öğrenci grubunda \%62,2, halk grubunda \%78,8) radyoaktif atıkların boşaltıldığı bir nehirde yaşayan balıkları yiyen insanlara da radyasyonun geçeceğini düşündükleri görülmektedir. Radyasyona maruz kalmış besinleri tüketen canlıların durumuyla radyoaktif madde içeren besinleri tüketen canlıların durumu birbirinden tamamen farklıdır. Fiziksel şartların değişmesi radyoaktif maddelerin radyoaktif özelliklerini değiştirmez. Radyoaktif atıklar içerisinde radyoaktif özellik gösteren maddeler bulunmaktadır. Bu atıklar uygun şekilde muhafaza edilmediği takdirde boşaltıldıkları bölgenin toprağına ve suyuna nüfuz ederek başka bölgelere taşınabilirler. Dolayısıyla radyoaktif atıkların bir nehre boşaltılması durumunda, atıktaki radyoaktif maddeler suya, buradan suda yaşayan balıklara ve buradan da balıkları tüketen insanlara geçebilir. Radyasyona maruz kalmış bir madde ile radyoaktif bir madde birbirinden tamamen farklı olmasına rağmen bu çalışmaya katılan kişilerin her iki maddenin de radyasyon yaydığını düşündükleri görülmektedir. Aynı şekilde, radyasyona maruz kalmış kişilerin vücutlarında radyoaktif madde bulunmadığ için kan, ter veya başka bir vücut sıvısı ile maruz kaldıkları radyasyonu etraflarına yaymayacak olmalarına rağmen, bu çalışmaya katılanların büyük bir kısmının bu kişilerin de radyoaktif bir maddeymiş gibi radyasyon yayacaklarını düşündükleri görülmektedir. 
Çalışmayakatılankişilerinradyasyonuninsanvücudundabiriktiğineinandıklarıgörülmektedir. Radyasyona maruz kalma durumu anlık olduğu için radyasyon kaynağından uzaklaşıldığında radyasyona maruz kalma durumu sona erer ve bu maruz kalınan radyasyon maddede birikmez. Buna rağmen bu çalışmanın sonuçlarında görüldüğü gibi literatürde de insanların, radyasyonun maddede birikeceğine, radyasyona maruz kalınması durumunda maddenin radyasyonu, süngerin suyu emmesi gibi emeceğine ve yapısında hapsedeceğine inandıkları görülmektedir (Eijkelhof, 1990; Prather ve Harrington, 2001). Ayrıca literatürde, radyoloji bölümünde okuyan öğrencilerin, röntgen odalarının duvarlarının ve havasının da radyoaktif olacağına, iyi havalandırılarak bu odalarda radyasyonun birikmesinin engellenebileceğine inandıkları görülmektedir (Mubeen, Abbas ve Nisar, 2008).

Aynı şekilde; radyasyonun insan sağlığını etkilemesi ve kalıcı bir etkiye neden olabilmesi için radyasyonun türü, dozu, radyasyon kaynağına olan uzaklık ve etkilenme süresi gibi faktörlerin etkisi olmasına rağmen, çalı̧̧maya katılan kişilerin büyük bir kısmının bu faktörleri dikkate almaksızın, her türlü radyasyonun insanlarda sakatllğa, mutasyona, zekâ geriliğine neden olacağını ve doğacak çocukları etkileyeceğini düşündükleri görülmektedir. Çalışmanın bu sonucu, insanların benzer düşüncelere sahip olduğunu gösteren literatür sonuçlarıyla örtüşmektedir (Hammick, Tutt ve Tait, 1998; Matsuura, 1997). 


\section{Kaynaklar}

Baran, M. (2013). Yaşam temelli probleme dayal öğrenme yönteminintermodinamik konusunun öğretinine etkisi. (Yayımlanmamış Doktora Tezi). Atatürk Üniversitesi, Eğitim Bilimleri Enstitüsü, Erzurum.

Cleveland, R. F., ve Ulcek, J. L. (1999). Questions and answers about biological effects and potential hazards of radiofrequency electromagnetic fields. Washington: Office of Engineering and Technology Federal Communications Commission.

Dural, G., ve Ruacan, Ş. (2001). Elektromanyetik dalgalar ve insan sağlığı (S1kça sorulan sorular ve yanıtları). Ankara: Tübitak- Bilten.

Eijkelhof, H. M. (1990). Radiation and risk in physics education. Universiteit Utrecht. [Available online at: http://www.cdbeta.uu.nl/tdb/fulltext/199003-duit.pdf ], Retrieved on October 2, 2014.

Eijkelhof, H. M. (1996). Radiation risk and science education. Radiation protection dosimetry, 68 (3-4), s. 273-278.

Eijkelhof, H., ve Millar, R. (1988). Reading about chernobyl: the public understanding of radiation and radioactivity. School Science Review, 70 (251), s. 35-41.

Fastman, S. M. (1988, July). Understandin radiation. Best's Review, 89 (3), s. 74.

Hammick, M., Tutt, A., \& Tait, D. M. (1998). Knowledge and perception regarding radiotherapy and radiation in patients receiving radiotherapy: A qualitative study. European Journal of Cancer Care, 7 (2), s. 103-112.

Henriksen, E. K. (1996). Laypeople's understanding of radioactivity and radiation. Radiation Protection Dosimetry, 64 (3-4), s. 191-196.

Henriksen, E. K., ve Jorde, D. (2001). High school students' understanding of radiation and the environment: Can museums play a role? Science Education, 85 (2), s. 189-206.

Janssen, J. H., ve Wellens, H. J. (1989). What do medical students know about in-hospital radiation hazards? Angiology, 40 (1), s. 36-38.

Kilinç, A., ve Salman, S. (2007). Okul deneyimi derslerine yönelik tutum ölçeği geliştirilmesi. Gazi Eğitim Fakültesi Dergisi, 27 (1), s. 23-35.

Lijnse, P. L., Eijkelhof, H. M., Klaassen, C. W., ve Scholte, R. L. (1990). Pupils' and mass media ideas about radioactivity. International Journal of Science Education, 12 (1), 67-78.

Matsuura, T. (1997). How to understand the radiation effects of small dose-some critical comments on international commission on radiological protection (ICRP) recommendations. Second International Conference on Isotopes (2ICI). Sydney, Australia.

Matsuura, T., ve Iır, Y. (1994). The importance of making right knowledge about radiation popular-activity of "radiation education forum". Tokyo, Japan: Radiation Education Forum.

McMillan, J. H., ve Schumacher, S. (2006). Research in education: Evidence-based inquiry (6th Edition). London: Pearson/Allyn and Bacon.

Millar, R., ve Gill, J. S. (1996). School students' understanding of processes involving radioactive substances and ionizing radiation. Physics Education, 31 (27), s. 27-33.

Millar, R., Klaassen, K., ve Eijkelhof, H. (1990). Teaching about radioactivity and ionising radiation: an alternative approach. Physics Education, 25, s. 339-342.

Mubeen, S. M., Abbas, Q., ve Nisar, N. (2008). Knowledge about ionising and non-ionising radiation among medical students. Journal of Ayub Medical College, 20 (1), s. 118-121.

Nakipoğlu, C., ve Bülbül, B. (200). Ortaöğretim kimya derslerinde yapısalcı (constructivist) öğrenme kuramı çerçevesinde "Çekirdek Kimyası" ünitesinin öğretimi. Balıkesir Üniversitesi Fen Bilimleri Enstitüsü Dergisi, 2 (1), s. 76-87. 
Marmara Üniversitesi Atatürk Eğitim Fakültesi Eğitim Bilimleri Dergisi / Journal of Educational Sciences

YIl: Haziran 2016 • Cilt-Sayı $44 \cdot$ ISSN: I300-8889 • ss. I-I3

Neumann, S., ve Hopf, M. (2012). Students' conceptions about 'radiation': Results from an explorative interview study of 9th grade students. Journal of Science Education and Technology, 21 (6), s. 826834.

Oppenheim, A. N. (1966). Questionnaire design, interviewing and attitude measurement. London and New York: Pinter Publishers.

Prather, E. E., ve Harrington, R. R. (2001). Student understanding of 1onizing radiation and radioactivity. Journal of College Science Teaching, 31 (2), s. 89-93.

Prather, E. (2005). Students' beliefs about the role of atoms in radioactive decay and half-life. Journal of Geoscience Education, 53, s. 345-354.

Tutty, L. M., Rothery, M. A., ve Grinnell, R. M. (1996). Qualitative research for social workers. Wiscasset: Allyn and Bacon.

Yalçın, A., ve Kılıç, Z. (2005). Öğrencilerin yanlış kavramaları ve ders kitaplarının yanlış kavramalara etkisi örnek konu: radyoaktivite. Gazi Eğitim Fakültesi Dergisi, 25 (3), s. 125-141.

Yıldırım, A., ve Şimşek, H. (2008). Sosyal bilimlerde nitel araştırma yöntemleri. Ankara: Seçkin Yayıncilık. 
